\title{
Islamic Religious Education Textbook Based on Contextual Teaching and Learning Model Valid for Higher Education
}

\author{
Azwar \\ Geography Education Department \\ STKIP PGRI Sumatera Barat \\ Padang, Indonesia \\ makmurazwar@gmail.com
}

\author{
Jarudin \\ Counseling Guidance \\ Education Department \\ STKIP PGRI Sumatera Barat \\ Padang, Indonesia \\ jarudinkasim@yahoo.com
}

\author{
Febri Yanti \\ Biology Education Department \\ STKIP PGRI Sumatera Barat \\ Padang, Indonesia \\ febriyanti1985@yahoo.co.id
}

\begin{abstract}
Islamic Religious Education (IRE) at university occupies a key position, functionally integrated with various disciplines. IRE plays an agent of student character formation that is praiseworthy, tough, honest and courageous in accordance with Islamic values. However, a lot of questionable policies and strategies of IRE in college. In STKIP PGRI Sumatera Barat, the IRE subject is general basic subjects (MKDU) which are given only once until the students complete their studies. The extent of REI's material content becomes an obstacle for lecturers at STKIP PGRI Sumatera Barat. Thus, the lecturers of IRE should be able to find the right way of conveying the IRE. Lecturers are required to have sufficient knowledge about IRE and have the ability to develop IRE in accordance with the demands of the times. Therefore, the development of IRE textbook based on Contextual Teaching and Learning (CTL) model for universities. The aim of the study is to develop an Islamic Religious Education textbook based on Contextual Teaching and Learning (CTL) model that is valid. The type of this research is research and development by using the ADDIE model (Analysis, Design, Develop, Implementation, and Evaluation). This study is limited to the textbook validity test stages. The results showed that the textbook that has been developed is categorized very validly with the validation value $90.26 \%$. IRE textbook based on Contextual Teaching and Learning (CTL) model can be used in learning IRE in STKIP PGRI Sumatera Barat.
\end{abstract}

Keywords-textbooks, Islam, CTL; validity, College

\section{INTRODUCTION}

Islamic Religious Education (IRE) in universities is one of the areas of study that gets a lot of attention from various circles. This is because IRE has a very strategic role in improving human resources on moral, ethical, and religious aspects. Within the IRE there are complex problems and require the immediate response. In IRE there are complex problems and require immediate treatment, such as the quality, function, and role of IRE in universities. According to Nurlaila 2011, improving the quality of IRE is expected to be able to solve the multidimensional crisis in our country, especially concerning the moral-ethical aspect so that learners become human beings who believe and cautious to God Almighty.

IRE at university occupies a key position, functionally integrated with various disciplines. IRE plays an agent of student character formation that is praiseworthy, tough, honest and courageous in accordance with Islamic values (Kosim, 2015). However, there are many questionable policies and strategies of IRE in Higher Education. The problematic education of IRE can arise in all other external aspects, such as teaching methods, learning facilities, and infrastructure. However, problems that may arise in all these aspects can be covered with teachers who can always manage the best possible learning process (Fajri and Taufiqurrahman, 2017). Currently, most educational institutions, especially universities in West Sumatera do not provide the portion and enough space to teach IRE. Likewise with STKIP PGRI Sumatera Barat, IRE subject are general basic subjects (MKDU) which are given only once until the students complete their studies. The extent of REI's material content becomes an obstacle for lecturers at STKIP PGRI Sumatera Barat. Thus, lecturers should be able to find the right way to deliver IRE. Lecturers are required to have sufficient knowledge about IRE and have the ability to develop IRE in accordance with the demands of the times. Therefore, the development of IRE textbook based on Contextual Teaching and Learning (CTL) model for universities.

Contextual Teaching and Learning (CTL) is defined as away to introduce content using a variety of activelearningtechniques designed to help students connectwhat they already know to what they are expected tolearn and to construct new knowledge from the analysisand synthesis of this learning process (Hudson and Whisler, 2017). CTL is a grassroots initiative that has emerged from teachers' efforts to buildupon situated-cognition research and integrate into one approach a number ofvalidated strategies that are too often employed independently of one another (Glynn and Winter, 2004).

IRE textbooks based on CTL model can be a solution in Islamic religious learning in college. 
Development of textbooks IRE-based on CTL model can bridge between the material of Islam with the real world problems faced by students in the reality of life. As well as to form the character of a student who is praised, tough, honest and courageous in accordance with Islamic values. This study aims to produce a textbook IRE based on CTL valid model that can be used in STKIP PGRI Sumatera Barat.

\section{METHOD}

This research was conducted on semester even 2017/2018 at STKIP PGRI Sumatera Barat. The type of research used is the research and development using the ADDIE models. This model consists of 5 steps, namely: analysis, design, development, implementation, and evaluation. This study is limited to the textbook validity test stages. Requesting the willingness of lecturers of Islamic education and lecturers of Indonesian Language and Literature Education to become a validator of the concepts made, both from the aspects of the material, presentation, and language in the design of textbooks. Requesting the willingness of the lecturer to assess the questionnaire of validity test given. Revise the Textbook based on validation made by the validators.

Data collected from this research is the result of validation of textbook by an expert which analyzed by using descriptive statistic. Techniques of data analysis validator assessment results are adjusted with the Riduwan formula (2011: 22) as follows:

Validity value $=$

(Score obtained)/(Maximum score) X 100\%

The level of achievement of the validity category of the textbook uses the Purwanto classification (2007: $82)$ in Table 1.

TABLE 1: EVALUATION CATEGORIES OF TEXTBOOKS.

\begin{tabular}{|c|c|c|}
\hline No & Achievement Level (\%) & Categories \\
\hline 1 & $90-100$ & Very valid \\
\hline 2 & $80-89$ & Valid \\
\hline 3 & $65-79$ & Quite valid \\
\hline 4 & $55-64$ & Less valid \\
\hline 5 & $0-55$ & Very less valid \\
\hline
\end{tabular}

\section{RESULTS AND DISCUSSION}

The IRE textbook based on CTL model is a textbook for colleges that contains a description of the material outlined in accordance with the steps of the CTL learning model. In the IRE textbook learning materials based on the CTL model students can connect learning material with real life. For example, when students learn about Thaharah materials using CTL models the students understand how important it is to maintain cleanliness and sanctity of body, clothes, equipment and environment. After studying the Thaharah material then students can apply Thararah knowledge in their life. Students become clean and healthy individuals born inward. Hygiene and health are the greatest capital for human and social survival. Likewise, when students learn material morality and noble character by using CTL learning models. Students can follow the example the attributes of the Prophet, namely Sidik, Amanah, Tabligh and Fathanah (STAF). When students have understood the nature of STAF well and correctly, then the student can internalize it in their lives. So STAFF becomes a habit wherever they are and whatever.

The IRE textbook based on CTL model contains the tasks that must be done by the students until the completeness of learning is achieved. Contextual Teaching and Learning model can bridge between IRE materials with real-world problems faced by students in the reality of life. CTL approach is an approach involving students' knowledge and experience in daily life (Selvianiresa and Prabawanto, 2017). The IRE textbook based on CTL model has been successfully designed which includes cover, introduction, course identity, learning achievements, materials, learning activities, and summative questions. The sequence of material from this course has been systematically arranged. In the syllabus there is a learning material consisting of 12 chapters with 16 times learning activities. The material in the syllabus is in accordance with the standard of competence that must be achieved by the students.

On the cover, there are titles designed, namely Islamic Religious Education Textbook Based on Contextual Teaching and Learning for Higher Education, author's name and college name. The identity, of course consists of subject/sks, material, and time. The designed learning materials are adapted to the indicators and learning objectives. Learning activities are arranged based on the steps of CTL learning model to complete learning process can be achieved. Summative questions are designed in accordance with the learning objectives of each material and placed at the end of each material. Similar research has also been conducted by Megahati et al, 2015 on the design of "Student Worksheets Based on Mastery Learning in Genetics Subject".

Validation were performed by two validators who are experts in the field against. The data is then processed to obtain the average score of the validity of the IRE textbook based on CTL modelfor higher education can be seen in Table 2 . 
TABLE 2. THE RESULTS OF TEXTBOOK VALIDITY BY 2 VALIDATORS

\begin{tabular}{|l|c|c|}
\hline \multicolumn{1}{|c|}{ Assessment Standards } & $\begin{array}{c}\text { The value of validity } \\
(\%)\end{array}$ & Categories \\
\hline Material Aspects & 92,05 & Very valid \\
\hline Aspect of Presentation & 90 & Valid \\
\hline $\begin{array}{l}\text { Aspects of Readability } \\
\text { and Language }\end{array}$ & 88,75 & Quite valid \\
\hline Average & 90,26 & Less valid \\
\hline
\end{tabular}

Based on table 2, the validity test results performed, on the material aspect has very valid criteria with $92.05 \%$ validation value. Although the criteria are very valid in terms of material, there are some that should be revised according to the suggestion of the validator. But in general, IRE textbookbased on CTL model have been referring to the curriculum and learning objectives contained in the syllabus. Based on the analysis of curriculum conducted, the explanation of Islamic religious education material is in accordance with the standards of competence and basic competence. The teaching program that will be submitted through the media to the students must be in accordance with the applicable curriculum in terms of content, structure, and material depth (Djamarah and Basri, 2006).

Aspects of presentation of IRE textbook based on CTL has very valid criteria with a validation value of $90 \%$ but not independent of the revisions suggested by the validator. The revisions made are the parts of the drawings used should be more interesting students. Benefits of learning media in the learning process is the lesson will attract more students so that it can grow the motivation to learn, learning materials will be more clear meaning that can be better understood by the students and allows students to master the goal of better learning (Rusman, 2012).

Language aspect has valid criteria with validation value $88,75 \%$. But not apart from the revisions suggested by the validator. Revisions made is to correct the error of writing the words on learning materials to be tailored to the EYD and improve the writing of the term used to be easy to understand students. An instrument is said to be valid if the instrument can be used to measure what should be measured (Sugiyono, 2007).

Validation results conducted by two validators who are lecturers who are experts in the field of IRE and education of Indonesian language and literature stated that the IRE textbook based on CTL has been very valid with the average $90.26 \%$ which means the validity of this result can be justified. The same research result has also been done by Wati et al, 2018 where the validation of concept map based module in Evolution course is at very valid criterion that is $92,18 \%$. In contrast to the results of the validity of Student worksheet based on Mastery learning in
Genetics subject are on valid criteria with a value of 88\% (Megahati et al., 2016). The development of textbooks using the 4-D model in improving the success of Islamic education learning is valid criteria (Fajri and Taufiqurrahman, 2017). Based on the above, the criteria of a textbook that has been described above has been met by IRE textbooks based on CTL researchers develop.

\section{ACKNOWLEDGMENT}

The authors would like to thank DRPM DIKTI for helping in funding this research. Thanks to all parties who have helped in the research and writing of this manuscript. Thank you to Dr. Ruth Rize Paas Megahati who has helped in writing the manuscript and her suggestions.

\section{REFERENCES}

[1] Nurlaila, 2011.Model-Model Pengembangan Pendidikan Agama Islam Di Sekolah/PerguruanTinggi. TA'DIB. 16(2): 247-272

[2] Kosim, N. 2015. Pengembangan dan Aplikasi Pembelajaran PAI di SD. Jurnal Qathrunâ. 2 (2):

$$
\text { 121-142. }
$$

[3] Fajri, K and Taufiqurrahman (2017)."Pengembangan Buku Ajar Menggunakan Model 4d Dalam Peningkatan Keberhasilan Pembelajaran Pendidikan Agama Islam" . JPII2(1): 1-15.

[4] Hudson, C. C and V. R. Whisler (2017). "Contextual Teaching and Learning for Practitioners". Systemics, Cybernetics and Informatics.6(4): 54-59.

[5] Glynn, S. M. and L. K. Winter (2004). “Contextual Teaching and Learningof Science in Elementary Schools". Journal of Elementary Science Education.16(2): 51-63.

[6] Djamarah danSyaifulBahri. 2006. StrategiBelajarMengajar. Jakarta: RinekaCipta

[7] Megahati, et al., (2015).Perancangan Lembar Kerja Mahasiswa (LKM) BerbasisMastery Learning Pada Mata Kuliah Genetika.SEMIRATA 2015 Pontianak.

[8] Purwanto dkk, 2007.Pengembangan Modul. Jakarta: Pustekom

[9] Riduwan. 2011. Pengantar Statistika Untuk Penelitian Pendidikan, Sosial, Ekonomi, Komunikasi, dan Bisnis. Bandung: Alfabeta.

[10] Rusman. 2012. Model-model Pembelajaran. Depok: Raja Grafindo Persada

[11] Selvianiresa, D and S. Prabawanto(2017). “Contextual Teaching and Learning Approach of

[12] Mathematics in Primary Schools".Journal of Physics: Conf. Series 895.

[13] Wati, M., V. Fitriani and R. R. P. Megahati(2018). "Design and Validity of Module Based on Concept Map In The Course Of Evolusi". International Journal of Advanced and Research.6(2): 658-661.

[14] Sugiyono. 2007. StatistikaUntukPenelitian. Bandung: Alfabeta

[15] Megahati, R.R.P., D, Susanti, and F Yanti(2016)."Perancangan Lembar Kerja Mahasiswa (LKM) Berbasis Mastery Learning Pada Mata Kuliah Genetika".Unnes Journal of Biology Education.5(1): 50-54. 
